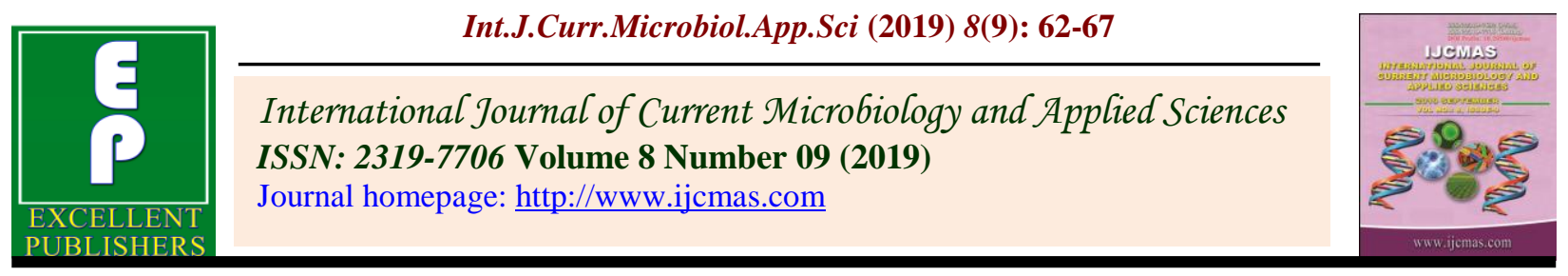

Original Research Article https://doi.org/10.20546/ijcmas.2019.809.009

\title{
Economic Analysis of Marketing of Pigeonpea in Latur District of Maharashtra, India
}

\author{
T.S. Swami, J.L. Katkade* and R.D. Shelke \\ Department of Agricultural Economics, College of Agriculture, Latur-413512, Vasantrao \\ Naik Marathwada Krishi Vidyapeeth, Parbhani, Maharashtra, India \\ *Corresponding author
}

\begin{tabular}{|l|}
\hline Ke y w o r d s \\
Pigeonpea, Marketing \\
cost, Marketing \\
margin, Price spread, \\
Cost-A
\end{tabular}

\section{A B S T R A C T}

Pigeonpea (Cajanus cajan) is a often cross-pollinated, diploid, grain. It is the fourth most important food legume in the world after dry bean (Phaseolus vulgaris L.), field pea (Pisum sativum) and chickpea (Cicer arientinum L.) The present study on marketing cost, marketing margin and price spread of pigeonpea was conducted in Latur market. For the present study different marketing channels, marketing margins, price spread and producers share in consumer's rupee were calculated. The study was conducted for the year 2017-2018 in Latur market. Maximum percentage of produce of pigeonpea was sold through Channel-III. Producer share in consumer's rupee was maximum in Channel-III (96.78 per cent) and minimum in Channel-II (95.79 per cent). The results revealed that quantity of pigeonpea as $0.42,3.09$ and 5.23 quintals were marketed through channel-I, channel-II, and channel-III, respectively, Thus total marketed surplus of pigeonpea 8.74 quintals, respectively. Non availability of labour at time of harvesting, Attack of pest and disease, Lack of knowledge about improved practices, High rate of inputs, Weed problem were major constraints of pigeonpea growers.

\section{Introduction}

Pigeonpea (Cajanus cajan) is a often crosspollinated, diploid, grain. It is the fourth most important food legume in the world after dry bean (Phaseolus vulgaris L.), field pea (Pisum sativum) and chickpea (Cicer arientinum L.). It is also known as arhar, tur dal, red gram. Since its domestication in South Asia at least 3500 years ago, its seed have become a common food grain. Today pigeonpea is widely cultivated in all tropical and semi tropical regions of both the old and new worlds. In India pigeonpea was grown on 3.96 million/ha area with total production of 2.56 million/tones with an average productivity of $646 \mathrm{~kg} / \mathrm{ha}$ in the year 2015-16. In India, Maharashtra is the leading state in pigeonpea production (700000 tons). The other states like Uttar Pradesh (500000 tons), Karnataka (300000 tons), Madhya Pradesh (300000 tons), Gujarat (100000 tons), Rajasthan, Haryana, Punjab, Tamil Nadu, Orrisa and Bihar also cultivated pigeonpea. 
Marathwada region has an area of 64,525 sq. $\mathrm{km}$., which is about 12 per cent of the Maharashtra state. North side is bounded by Khandesh region east side by Vidarbha region and south side by Northern boundary of Andhra Pradesh and Western part by Pune division. In Latur district area under pigeonpea crop is 1162 lakh/ha with production 309 tonnes and productivity 266 $\mathrm{kg} /$ ha year (2015-16). The study on marketing pigeonpea will provide the information on marketing margin and price spread.

\section{Materials and Methods}

In pigeonpea various agencies, perform the different marketing functions in sequence as to move the produce from the place of production to the ultimate consumer.

It involved the different pathways to reach to the consumer with the help of different intermediaries. In the present study following marketing channels were found

Channel-I: Producer-consumer. Channel-II: Producer-wholesaler-consumer. Channel-III: Producer-trader-consumer.

\section{Marketing margin}

It is the difference between the price paid by consumers for farm produce and what the farmer receives. In a sense, the marketing margin is the price of all utility addition activities and functions performed by marketing functionaries. This price includes the expenses of agencies performing marketing functions and also their profit. Marketing margin is the difference in price received by the producer and price paid by the ultimate consumer. Marketing margins are the actual amounts received by the marketing agencies in the marketing process.

$\mathrm{MT}=\sum(\mathrm{Si}-\mathrm{Pi}) / \mathrm{Qi}$
Where,

$\mathrm{MT}=$ Total marketing margin

$\mathrm{Si}=$ Sale value of a product paid by $\mathrm{i}^{\text {th }}$ firm

$\mathrm{Pi}=$ Purchase value of a product paid by $\mathrm{i}^{\text {th }}$

firm

Qi = Quantity of product handled by its firm

\section{Price spread}

It refers to the difference between price paid by the consumer and price received by the producer for an equivalent quantity of the farm product.

This price spread consists of marketing costs and margins of the intermediaries.

It gives fair idea about relative efficiency of various marketing system and channels.

Price spread: Consumer's price - price received by farmer

Ps: Cp - Pf

Where,

$\mathrm{Cp}=$ consumer's price

$\mathrm{Pf}=$ price received by farmer

\section{Producers share in consumer's rupee}

It is the ratio of net price received by producer to the on price paid by consumer.

Can be calculated as:

Net price received by producer

Producers share in $=$ x 100

Consumer's rupee

Price paid by consumer 


\section{Results and Discussion}

Marketing cost, margin and price spread of pigeonpea marketing

Production, retention and marketed surplus of pigeonpea

Production, retention and marketed surplus of pigeonpea were calculated and are presented in Table 1. Production of pigeonpea was 9.57 quintal on 0.80 hectare and its retention of seed and consumption was 0.75 quintal. The results revealed that quantity of pigeonpea as $0.42,3.09$ and 5.23 quintals were marketed through channel-I, channel-II, and channel-III, respectively, Thus total marketed surplus of pigeonpea 8.74 quintals, respectively.

\section{Marketing cost of pigeonpea incurred by different intermediaries}

\section{Marketing cost of pigeonpea incurred by producer}

Item wise per quintal cost of marketing of pigeonpea incurred by producer in different channels was workout and is presented in Table 2. Results revealed that in channel-I total cost of marketing was Rs. 21.02 in which transporting charge was high as Rs. 18.28 with its share of 86.96 per cent, and weighing charges Rs. 2.74 with its share 13.03 per cent. In channel-II total cost of marketing incurred by producer was Rs. 108.28 in which transportation charge as Rs. 24.11 with its share of 22.26 and weighing charge 1.61 per cent. In channel-III total cost of marketing incurred by producer was Rs 52.27 in which transport charge as Rs. 41.17 with its share of 78.76 per cent.

\section{Cost of marketing of pigeonpea incurred by wholesaler}

Per quintal cost of marketing of pigeonpea incurred by wholesaler in channel-II were calculated and are presented in Table 3. The results revealed that total cost of marketing was Rs. 57.58 in which transportation charges were high as Rs. 14.97 with its share of 25.99 per cent followed by labour charge Rs. 8.96 with its share of 15.56 per cent

\section{Cost of marketing of pigeonpea incurred by trader}

Per quintal cost of marketing of pigeonpea incurred by trader III was calculated and is presented in Table 4. The results revealed that the total cost was Rs.61.17 in which transportation charge was high as Rs. 21.08 with its share 34.46 per cent followed by labour charge Rs. 18.20 with its share 29.75 per cent and shop tax were Rs. 1.34 with its share 2.19 per cent, and communication charges were Rs. 20.36 with its share 33.28 per cent.

Table.1 Production, retention and marketed surplus of pigeonpea through different channels

\begin{tabular}{|c|l|c|}
\hline S. No. & \multicolumn{1}{|c|}{ Particular } & $\begin{array}{c}\text { Crop } \\
\text { Pigeonpea }\end{array}$ \\
\hline $\mathbf{1 .}$ & Farm size (ha) & 0.80 \\
\hline $\mathbf{2 .}$ & Production (q) & $9.57(100)$ \\
\hline $\mathbf{3 .}$ & Retention for Seed \& Family consumption & $0.75(7.83)$ \\
\hline $\mathbf{4 .}$ & Marketed surplus in channel -I (q) (channel-I)- Producer-consumer. & $0.42(4.38)$ \\
\hline $\mathbf{5 .}$ & Marketed surplus in channel -II (q) (Channel-II)- Producer-wholesaler-consumer. & $3.09(32.28)$ \\
\hline $\mathbf{6 .}$ & Marketed surplus in channel-III (q) (Channel-III)- Producer-trader-consumer. & $5.23(54.64)$ \\
\hline $\mathbf{7 .}$ & Total marketed surplus (q) & $8.74(91.32)$ \\
\hline
\end{tabular}


Table.2 Cost of marketing of pigeonpea incurred by producer (Rs/q)

\begin{tabular}{|c|c|c|c|c|}
\hline S.No. & Particular & Channel - I & Channel-II & Channel - III \\
\hline 1. & Transport charges & $\begin{array}{c}18.28 \\
(86.96)\end{array}$ & $\begin{array}{c}24.11 \\
(22.26)\end{array}$ & $\begin{array}{c}41.17 \\
(78.76)\end{array}$ \\
\hline 2. & $\begin{array}{l}\text { Loading charges / } \\
\text { Unloading charges }\end{array}$ & --- & $\begin{array}{c}8.45 \\
(7.80)\end{array}$ & $\begin{array}{c}9.06 \\
(17.33)\end{array}$ \\
\hline 3. & Weighing charges & $\begin{array}{c}2.74 \\
(13.03)\end{array}$ & $\begin{array}{c}1.61 \\
(1.48)\end{array}$ & $\begin{array}{c}1.92 \\
(3.67)\end{array}$ \\
\hline 4. & Commission charges & --- & $\begin{array}{c}72.04 \\
(66.53)\end{array}$ & --- \\
\hline 5. & Market fee & --- & $\begin{array}{c}1.98 \\
(1.82)\end{array}$ & --- \\
\hline 6. & $\begin{array}{l}\text { Total cost incurred by } \\
\text { producer }\end{array}$ & $\begin{array}{l}21.02 \\
(100)\end{array}$ & $\begin{array}{c}108.28 \\
(100)\end{array}$ & $\begin{array}{l}52.27 \\
(100)\end{array}$ \\
\hline
\end{tabular}

(Figures in parentheses indicate percentage to total)

Table.3 Cost of marketing of pigeonpea incurred by wholesaler (Rs/qt)

\begin{tabular}{|c|c|c|c|c|}
\hline S.No. & Particular & Channel-I & Channel-II & Channel-III \\
\hline 1. & Labour charges & --- & $\begin{array}{c}8.96 \\
(15.56)\end{array}$ & --- \\
\hline 2. & Transport charges & --- & $\begin{array}{c}14.97 \\
(25.99)\end{array}$ & --- \\
\hline 3. & Electric charges & --- & $\begin{array}{c}1.26 \\
(2.18)\end{array}$ & --- \\
\hline 4. & Shop tax & --- & $\begin{array}{c}0.52 \\
(0.90)\end{array}$ & --- \\
\hline 5. & License charges & --- & $\begin{array}{c}0.13 \\
(0.22)\end{array}$ & --- \\
\hline 6. & Losses & --- & $\begin{array}{c}6.82 \\
(11.84)\end{array}$ & --- \\
\hline 7. & Market fee & --- & $\begin{array}{c}24.92 \\
(43.27)\end{array}$ & --- \\
\hline 8. & Total & --- & $\begin{array}{l}57.58 \\
(100)\end{array}$ & --- \\
\hline
\end{tabular}


Table.4 Cost incurred by trader for pigeonpea marketing

\begin{tabular}{|c|c|c|c|c|}
\hline S.No. & Particular & Channel-I & Channel-II & Channel-III \\
\hline 1. & Labour charges & --- & --- & $\begin{array}{c}18.20 \\
(29.75)\end{array}$ \\
\hline 2. & Transport charges & --- & --- & $\begin{array}{c}21.08 \\
(34.46)\end{array}$ \\
\hline 3. & Weighing charges & --- & --- & $\begin{array}{c}0.19 \\
(0.31)\end{array}$ \\
\hline 4. & Shop tax & --- & --- & $\begin{array}{c}1.34 \\
(2.19)\end{array}$ \\
\hline 5. & $\begin{array}{l}\text { Communication } \\
\text { charges }\end{array}$ & --- & --- & $\begin{array}{c}20.36 \\
(33.28)\end{array}$ \\
\hline 6. & Total & --- & --- & $\begin{array}{l}61.17 \\
(100)\end{array}$ \\
\hline
\end{tabular}

Table.5 Per quintal marketing cost, marketing margin and price spread in pigeonpea marketing

\begin{tabular}{|c|c|c|c|c|}
\hline S.No. & Particular & Channel-I & Channel-II & Channel-III \\
\hline 1. & $\begin{array}{l}\text { Net price received by producer } \\
\text { (producer's share in consumer rupee) }\end{array}$ & $\begin{array}{l}5178.98 \\
(99.59)\end{array}$ & $\begin{array}{l}5239.48 \\
(95.79)\end{array}$ & $\begin{array}{l}5448.98 \\
(96.78)\end{array}$ \\
\hline 2. & $\begin{array}{l}\text { Marketing cost incurred by pigeonpea } \\
\text { producer }\end{array}$ & $\begin{array}{l}21.02 \\
(0.40)\end{array}$ & $\begin{array}{l}108.28 \\
(1.97)\end{array}$ & $\begin{array}{l}52.27 \\
(0.92)\end{array}$ \\
\hline 3. & Price paid by wholesaler & - & $\begin{array}{l}5347.76 \\
(97.78)\end{array}$ & - \\
\hline 4. & Marketing cost incurred by wholesaler & - & $\begin{array}{l}57.58 \\
(1.05)\end{array}$ & - \\
\hline 5. & Margin of wholesaler & - & $\begin{array}{l}63.75 \\
(1.16)\end{array}$ & - \\
\hline 6. & Price paid by trader & - & - & - \\
\hline 7. & Marketing cost incurred by trader & - & - & $\begin{array}{l}61.17 \\
(1.08)\end{array}$ \\
\hline 8. & Margin of trader & - & - & $\begin{array}{l}67.70 \\
(1.20)\end{array}$ \\
\hline 9. & Price paid by consumer & $\begin{array}{l}5200 \\
(100)\end{array}$ & $\begin{array}{c}5469.09 \\
(100)\end{array}$ & $\begin{array}{c}5630.12 \\
(100)\end{array}$ \\
\hline 10. & Total marketing cost & $\begin{array}{l}21.02 \\
(0.40)\end{array}$ & $\begin{array}{l}165.86 \\
(3.03)\end{array}$ & $\begin{array}{l}67.70 \\
(1.20)\end{array}$ \\
\hline 11. & Total market margin & - & $\begin{array}{l}63.75 \\
(1.16)\end{array}$ & $\begin{array}{l}113.44 \\
(2.01)\end{array}$ \\
\hline 12. & Price spread & $\begin{array}{l}21.02 \\
(0.40)\end{array}$ & $\begin{array}{c}229.43 \\
(4.19)\end{array}$ & $\begin{array}{l}181.14 \\
(3.21)\end{array}$ \\
\hline
\end{tabular}

(Figures in parentheses indicate percentage to total) 


\section{Price spread in pigeonpea marketing}

Per quintal marketing cost, marketing margin and price spread in pigeonpea marketing with respect to different channels was estimated and is presented in Table 5. The results revealed that in regard to channel-I price received by producer was Rs. 5200 while cost incurred by producer was Rs. 21.02. Thus net price received by producer was Rs. 5178.98 with 99.59 per cent producer's share in consumer's rupee. In channel-II, price received by producer was Rs. 5469.09 while cost incurred by producer was Rs. 165.86. Thus net price received by producer was Rs 5239.48 with 95.79 per cent producer's share in consumer's rupee. It inferred that price paid by consumer 5469.09. In this channel marketing cost and marketing margin was Rs 165.86 and Rs. 63.75 , respectively. Thus price spread was Rs. 229.43.

In channel-III, price received by producer Rs. 5400.00 while cost incurred by producer was Rs. 52.27. Thus, net price received by producer was Rs. 5448.98 with 96.78 per cent producer's share in consumer's rupee. Further, trader had sold that produce to consumer at Rs. 5630.12. In this channel marketing cost and marketing margin was Rs. 67.70 and Rs. 113.44, respectively. Thus price spread was Rs. 181.14.

Maximum percentage of produce of pigoenpea was sold through Channel-III.
Producer share in consumer's rupee was maximum in Channel-III (96.78 per cent) and minimum in Channel-II (95.79 per cent). The results revealed that quantity of pigeonpea as $0.42,3.09$ and 5.23 quintals were marketed through channel-I, channel-II, and channelIII, respectively, Thus total marketed surplus of pigeonpea 8.74 quintals, respectively.

\section{References}

Gaikwad, A. N. 2004. Production and marketing management of Red gram in Solapur district. Unpublished M.Sc. (Agri.) Thesis, Submitted to M.P.K.V., Rahuri.

Gajbhiye, S.B. and Kakade S.J., 2011. Marketing of chickpea in Akola district of Maharashtra. International Journal of Commerce and Business Management; 4(8): 228-230.

Handiganur, A.Y., (1998). The production and marketing performance of pulses in Karnataka. Karnataka J. Agric. Econ, 43(5): 413-415.

Srivastava. S. C., B. S. Gupta and H. P. Singh., 2010, Economic analysis of marketing of soybean in Mandsaur District of Madhya Pradesh. Indian. J. Agril. Mktg., 24(8): 856.

Vyas, G. S. and T.V. Patel, 1994. Economics of production and marketing of chickpea in Karnataka state. International J. Agril. Sci, 3(2): 316163.

\section{How to cite this article:}

Swami, T.S., J.L. Katkade and Shelke, R.D. 2019. Economic Analysis of Marketing of Pigeonpea in Latur District of Maharashtra. Int.J.Curr.Microbiol.App.Sci. 8(09): 62-67. doi: https://doi.org/10.20546/ijcmas.2019.809.009 